\title{
INHIBITION OF CENTRAL ANGIOTENSIN II-INDUCED PRESSOR RESPONSES BY HYDROGEN PEROXIDE
}

\author{
M. R. LAUAR, D. S. A. COLOMBARI, P. M. DE PAULA, \\ E. COLOMBARI, L. M. CARDOSO, L. A. DE LUCA JR \\ AND J. V. MENANI* \\ Department of Physiology and Pathology, Dentistry School, São Paulo \\ State University (UNESP), Araraquara, São Paulo, Brazil
}

\begin{abstract}
Hydrogen peroxide $\left(\mathrm{H}_{2} \mathrm{O}_{2}\right)$, important reactive oxygen species produced endogenously, may have different physiological actions. The superoxide anion $\left(\mathrm{O}_{2}{ }^{-}\right)$is suggested to be part of the signaling mechanisms activated by angiotensin II (ANG II) and central virus-mediated overexpression of the enzyme superoxide dismutase (that dismutates $\mathrm{O}_{2} \cdot-$ to $\mathrm{H}_{2} \mathrm{O}_{2}$ ) reduces pressor and dipsogenic responses to central ANG II. Whether this result might reflect elevation of $\mathrm{H}_{2} \mathrm{O}_{2}$ rather than depletion of $\mathrm{O}_{2}{ }^{-}$has not been addressed. Here we investigated the effects of $\mathrm{H}_{2} \mathrm{O}_{2}$ injected intracerebroventricularly (i.c.v.) or ATZ (3-amino-1,2,4-triazole, a catalase inhibitor) injected intravenously (i.v.) or i.c.v. on the pressor responses induced by i.c.v. injections of ANG II. Normotensive male Holtzman rats $(280-320 \mathrm{~g}, n=5-13$ / group) with stainless steel cannulas implanted in the lateral ventricle were used. Prior injection of $\mathrm{H}_{2} \mathrm{O}_{2}(5 \mu \mathrm{mol} / 1 \mu \mathrm{l})$ or ATZ $(5 \mathrm{nmol} / 1 \mu \mathrm{l})$ i.c.v. almost abolished the pressor responses induced by ANG II $(50 \mathrm{ng} / 1 \mu \mathrm{l})$ also injected i.c.v. ( $7 \pm 3$ and $5 \pm 3 \mathrm{~mm} \mathrm{Hg}$, respectively, vs. control: $19 \pm 4 \mathrm{~mm}$ $\mathrm{Hg}$ ). Injection of ATZ (3.6 mmol/ $\mathrm{kg}$ b.wt.) i.v. also reduced central ANG II-induced pressor responses. Injections of $\mathrm{H}_{2} \mathrm{O}_{2}$ i.c.v. and ATZ i.c.v. or i.v. alone produced no effect on baseline arterial pressure. Central ANG II, $\mathrm{H}_{2} \mathrm{O}_{2}$ or ATZ did not affect heart rate. The results show that central injections of $\mathrm{H}_{2} \mathrm{O}_{2}$ and central or peripheral injections of ATZ reduced the pressor responses induced by i.c.v. ANG II, suggesting that exogenous or endogenous $\mathrm{H}_{2} \mathrm{O}_{2}$ may inhibit central pressor mechanisms activated by ANG II. (c) 2010 IBRO. Published by Elsevier Ltd. All rights reserved.
\end{abstract}

Key words: hypertension, reactive oxygen species, superoxide dismutase, arterial pressure, catalase inhibitor.

Superoxide anion $\left(\mathrm{O}_{2}^{-{ }^{-}}\right)$, hydroxyl radical $(\mathrm{HO})$ and hydrogen peroxide $\left(\mathrm{H}_{2} \mathrm{O}_{2}\right)$ known as reactive oxygen species (ROS) can be produced endogenously and act as cellular signaling molecules to regulate biological function (Adler et al., 1999; Chen et al., 2001; Zimmerman et al., 2002, 2004a; Rhee et al., 2003; Zimmerman and Davisson, 2004; Avshalumov et al., 2005; Bao et al., 2009). Superoxide dismutase (SOD), an important enzyme in the metabolism of ROS catalyzing the dismutation of $\mathrm{O}_{2}{ }^{--}$to form

*Corresponding author. Tel: +55-16-33016486; fax: +55-16-33016488. E-mail address: menani@foar.unesp.br (J. V. Menani).

Abbreviations: ANG II, angiotensin II; ATZ, 3-amino-1,2,4-triazole; AV3V, anteroventral third ventricle; $\mathrm{HO}$, hydroxyl radical; $\mathrm{H}_{2} \mathrm{O}_{2}$, hydrogen peroxide; HR, heart rate; i.c.v., intracerebroventricular; i.v., intravenous; MAP, mean arterial pressure; $\mathrm{O}_{2}{ }^{\cdot-}$, superoxide anion; ROS, reactive oxygen species; SOD, superoxide dismutase.
$\mathrm{H}_{2} \mathrm{O}_{2}$, is widely distributed in the CNS, where ROS are suggested to act as neuromodulators affecting neurotransmission and neuronal firing (Aizenman et al., 1989; Volterra et al., 1994; Zoccarato et al., 1995; Chen et al., 2001; Zimmerman et al., 2002; Zimmerman and Davisson, 2004; Avshalumov et al., 2005; Campese et al., 2007).

Angiotensin II (ANG II), the main peptide released by the activation of the renin-angiotensin system, acts centrally to produce pressor responses dependent on sympathetic activation and vasopressin secretion, as well as producing natriorexigenic and dipsogenic responses (Hoffman et al., 1977; Johnson et al., 1978; Johnson, 1985; Mahon et al., 1995; Fitzsimons, 1998). Previous studies have suggested that a decrease in ANG II-induced $\mathrm{O}_{2}{ }^{-}$ formation by central adenovirus-mediated overexpression of SOD abolishes pressor and dipsogenic responses to central injections of ANG II, suggesting that $\mathrm{O}_{2}{ }^{--}$is part of the signaling mechanisms activated by ANG II centrally (Zimmerman et al., 2002, 2004a; Zimmerman and Davisson, 2004). The evidence that ANG II induces $\mathrm{O}_{2}{ }^{--}$formation is reinforced by studies showing that central ANG II increases dihydroethidium fluorescence, a standard probe selective for $\mathrm{O}_{2}{ }^{-}$and that ANG II induces calcium influx dependent on $\mathrm{O}_{2} \cdot-$ (Zimmerman et al., 2004b, 2005). In addition, ANG II-induced ROS production is suggested to involve NADPH oxidase (Zimmerman et al., 2004a; Peterson et al., 2009).

Hydrogen peroxide is a relatively stable and diffusible ROS that may act centrally through different mechanisms modulating neuronal synaptic transmission. Excitatory or inhibitory responses to $\mathrm{H}_{2} \mathrm{O}_{2}$ acting centrally have been reported (Sorg et al., 1997; Volterra et al., 1994; Zoccarato et al., 1995, 1999; Sah et al., 2002; Wehage et al., 2002; Bao et al., 2005; Avshalumov et al., 2005; Takahashi et al., 2007). Centrally, $\mathrm{H}_{2} \mathrm{O}_{2}$ can block glutamate uptake by glial cells, which may result in an increase of extracellular glutamate levels enhancing neuronal excitability or even causing toxicity (Sorg et al., 1997; Volterra et al., 1994). On the other hand, it has also shown that $\mathrm{H}_{2} \mathrm{O}_{2}$ inhibits glutamate and increases GABA release or acts at ion channels, especially ATP-sensitive potassium channels $\left(\mathrm{K}_{\text {ATP }}\right.$ channels) causing neuronal hyperpolarization and reducing neuronal excitability (Zoccarato et al., 1995, 1999; Sah et al., 2002; Takahashi et al., 2007; Bao et al., 2005; Avshalumov et al., 2005).

Studies have shown the importance of $\mathrm{O}_{2}{ }^{--}$as part of the signaling mechanisms activated by ANG II, however, possible effects of other ROS, like $\mathrm{H}_{2} \mathrm{O}_{2}$, on ANG II-induced responses were not investigated yet. In spite of the controversies about a correlation between changes in

0306-4522/10 \$ - see front matter @ 2010 IBRO. Published by Elsevier Ltd. All rights reserved. doi:10.1016/j.neuroscience.2010.08.048 
SOD activity and $\mathrm{H}_{2} \mathrm{O}_{2}$ levels (Teixeira et al., 1998; Gardner et al., 2002; Chan et al., 2006; Kowald et al., 2006), central SOD overexpression might also reduce ANG IIinduced responses due to increases in $\mathrm{H}_{2} \mathrm{O}_{2}$ levels. Endogenously, $\mathrm{H}_{2} \mathrm{O}_{2}$ production may result from NADPH oxidase activity or mitochondrial respiration coupled to SOD pathway or monoamine oxidase activity (Maker et al., 1981; Zimmerman et al., 2004a; Peterson et al., 2009; Bao et al., 2005, 2009) and independently from the source, $\mathrm{H}_{2} \mathrm{O}_{2}$ might affect ANG II-induced responses through mechanisms that reduce neuronal excitability. Therefore, in the present study we investigated if exogenous $\mathrm{H}_{2} \mathrm{O}_{2}$ injected i.c.v. or the increase of endogenous $\mathrm{H}_{2} \mathrm{O}_{2}$ produced by i.c.v. injections of the catalase inhibitor ATZ (3-amino-1,2,4-triazole) could modify the pressor responses induced by i.c.v. ANG II. In addition, we also tested the effects of i.v. $\mathrm{H}_{2} \mathrm{O}_{2}$ or ATZ on the pressor response to ANG II i.c.v. or i.v.

\section{EXPERIMENTAL PROCEDURES}

\begin{abstract}
Animals
Normotensive male Holtzman rats (baseline MAP: $109 \pm 1 \mathrm{~mm} \mathrm{Hg}$ and baseline HR: $368 \pm 5 \mathrm{bpm}$ ) weighing 280 to $320 \mathrm{~g}$ were used. The animals were housed individually in stainless steel cages in a room with controlled temperature $\left(23 \pm 2{ }^{\circ} \mathrm{C}\right)$ and humidity $(55 \pm 10 \%)$. Lights were on from 7:00 AM to 7:00 PM. Guabi rat chow (Paulínia, SP, Brazil) and tap water were available ad libitum. The experimental protocols used in the present study were approved by the Ethical Committee for Animal Care and Use from Dentistry School of Araraquara, UNESP, Brazil.
\end{abstract}

\section{Surgery for the implant of i.c.v. cannulas}

Rats were anesthetized with ketamine $(80 \mathrm{mg} / \mathrm{kg}$ of body weight, Cristalia, Itapira, SP, Brazil) combined with xylazine $(7 \mathrm{mg} / \mathrm{kg}$ of body weight, Agener Uniao, Embu-Guacu, SP, Brazil) and placed in a stereotaxic frame (model 900, David Kopf Instruments, Tujunga, CA, USA). Bregma and lambda were positioned at the same horizontal level. A stainless steel cannula $(10 \times 0.6 \mathrm{~mm}$ o.d.) was implanted into the lateral ventricle (LV) using the coordinates $0.3 \mathrm{~mm}$ caudal to bregma, $1.6 \mathrm{~mm}$ lateral to midline and $3.5 \mathrm{~mm}$ below of the skull bone. The cannulas were fixed to the cranium using dental acrylic resin and jeweler screws.

Rats were maintained in individual cages with free access to water and food pellets. Rats received a prophylactic dose of penicillin $(30,000 \mathrm{IU})$ given i.m. and a s.c. injection of the analgesic Ketoflex (ketoprofen 1\%, $0.03 \mathrm{ml} / \mathrm{rat}$, Mundo Animal, Sao Paulo, $\mathrm{SP}$, Brazil) post-surgically.

\section{Arterial pressure and heart rate recordings}

Mean arterial pressure (MAP) and heart rate (HR) were recorded in unanesthetized rats. Five days after brain surgery, rats were anesthetized again with ketamine ( $80 \mathrm{mg} / \mathrm{kg}$ of body weight) combined with xylazine ( $7 \mathrm{mg} / \mathrm{kg}$ of body weight) and a polyethylene tubing (PE-10 connected to a PE-50, Clay Adams, Parsippany, NJ, USA) was inserted into the abdominal aorta through the femoral artery. At the same time, in some rats, a polyethylene tubing was inserted into the femoral vein for drug administration. Venous and/or arterial catheters were tunneled s.c. and exposed on the back of the rat to allow access in unrestrained, freely moving rats. To record pulsatile arterial pressure, MAP and HR, the arterial catheter was connected to a Stathan Gould (P23 Db) pressure transducer (Sthatan Gould, Cleveland, OH, USA) cou- pled to a pre-amplifier (model ETH-200 Bridge Bio Amplifier, CBSciences Inc., Dover, NH, USA) that was connected to a Powerlab computer data acquisition system (model Powerlab 16SP, ADInstruments, Castle Hill, NSW, Australia).

\section{Central injections}

The i.c.v. injections were made using $10 \mu \mathrm{l}$ Hamilton syringes connected by polyethylene tubing (PE 10) to the injector needles that were $2.0 \mathrm{~mm}$ longer than the guide cannula implanted in the brain. The volume of i.c.v. injections was $1 \mu$ l.

\section{Drugs}

Hydrogen peroxide $\left(\mathrm{H}_{2} \mathrm{O}_{2}, 5 \mu \mathrm{mol} / 1 \mu \mathrm{l}\right)$, angiotensin II (ANG II, 50 $\mathrm{ng} / 1 \mu \mathrm{l})$ and 3-amino-1,2,4-triazole (ATZ, $5 \mathrm{nmol} / 1 \mu \mathrm{l})$, purchased from Sigma Chemical Co. (St. Louis, MO, USA), were injected i.c.v. The same doses of $\mathrm{H}_{2} \mathrm{O}_{2}$ and $A N G$ II in a volume of $0.1 \mathrm{ml}$ of vehicle were injected i.v. ATZ at the dose of $3.6 \mathrm{mmol} / \mathrm{kg}$ of body weight was also injected i.v. Angiotensin II and ATZ were dissolved in saline and $\mathrm{H}_{2} \mathrm{O}_{2}$ was diluted in phosphate buffered saline (PBS, pH 7.2). PBS or saline were injected i.c.v. or i.v. in control experiments. The doses of ANG II, $\mathrm{H}_{2} \mathrm{O}_{2}$ and $A T Z$ used in the present study were based on previous studies that tested the cardiovascular effects of these drugs injected central or peripherally (Menani et al., 1990; Aragon et al., 1991; Cardoso et al., 2006, 2009).

\section{Histology}

At the end of the experiments, $2 \%$ Evans blue solution ( $1 \mu \mathrm{l})$ was injected i.c.v. Immediately after dye injection, the animals were deeply anesthetized with sodium thiopental $(70 \mathrm{mg} / \mathrm{kg}$ of body weight, i.p., Cristalia, Itapira, SP, Brazil). Saline followed by $10 \%$ buffered formalin was perfused through the heart. The brains were removed, fixed in $10 \%$ buffered formalin, frozen, cut coronally (50 $\mu \mathrm{m}$ sections), stained with Giemsa stain (that stains cell nuclei) and analyzed by light microscopy to confirm the injections into the LV.

\section{Statistical analysis}

The results are reported as means \pm standard error of means (SEM). One-way analysis of variance (ANOVA) and NewmanKeuls tests were used for comparisons. Differences were considered significant at $P<0.05$.

\section{Experimental protocols}

Cardiovascular responses produced by ANG II i.c.v. combined with $\mathrm{H}_{2} \mathrm{O}_{2}$ i.c.v. MAP and $\mathrm{HR}$ were recorded one day after the surgery for the implant the arterial catheter. Around $20 \mathrm{~min}$ after starting the recordings of MAP and HR, PBS $(1 \mu \mathrm{l})$ or $\mathrm{H}_{2} \mathrm{O}_{2}$ $(5 \mu \mathrm{mol} / 1 \mu \mathrm{l})$ was injected i.c.v. followed by an i.c.v. injection of ANG II $(50 \mathrm{ng} / 1 \mu \mathrm{l}) 1 \mathrm{~min}$ later. MAP and HR recordings stopped $30 \mathrm{~min}$ after ANG II injection and started again $4 \mathrm{~h}$ later, when the same i.c.v. treatments were repeated in the same rats in a counterbalanced design.

Cardiovascular responses produced by ANG II i.c.v. combined with ATZ i.c.v. A protocol similar to that described above to test the effects of the combination of $\mathrm{H}_{2} \mathrm{O}_{2}$ and ANG II i.c.v. was also used in a different group of rats to test the cardiovascular responses to the combination of ATZ $(5 \mathrm{nmol} / 1 \mu \mathrm{l})$ and ANG II (50 $\mathrm{ng} / 1 \mu \mathrm{l})$ i.c.v., except that ATZ instead of $\mathrm{H}_{2} \mathrm{O}_{2}$ was injected i.c.v. $10 \mathrm{~min}$ before ANG II.

Cardiovascular responses produced by ANG II i.v or i.c.v. combined with ATZ i.v. A protocol similar to that described above to test the effects of the combination ATZ and ANG II i.c.v. 


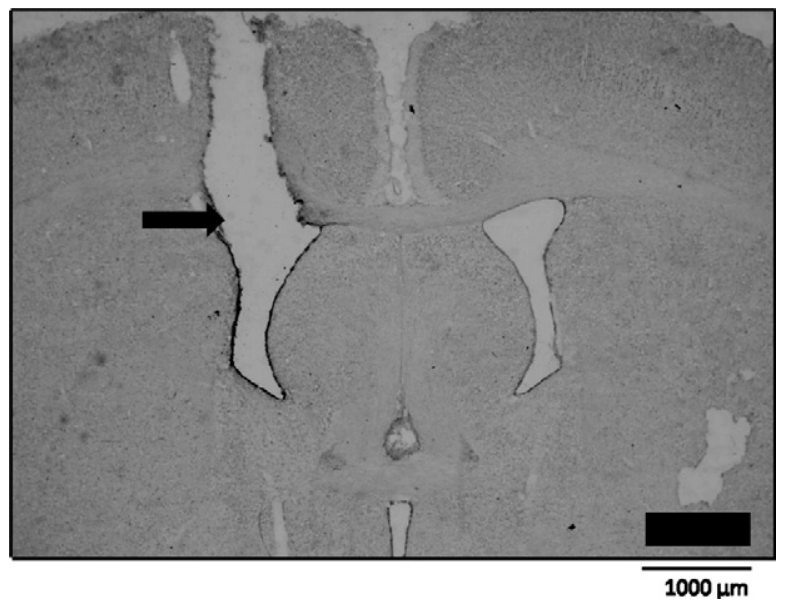

Fig. 1. Photomicrograh showing the typical site of injections into the lateral ventricle (arrow).

was also used in a different group of rats to test the cardiovascular responses to the combination of ATZ ( $3.6 \mathrm{mmol} / \mathrm{kg}$ of body weight) i.v. and ANG II (50 ng/0.1 ml) i.v.

In the same rats, 5 min after ANG II i.v., it was also injected ANG II $(50 \mathrm{ng} / 1 \mu \mathrm{l})$ i.c.v.

Cardiovascular responses produced by i.v. ANG II combined with i.v. $\mathrm{H}_{2} \mathrm{O}_{2}$. A potentially confounding factor is that $\mathrm{H}_{2} \mathrm{O}_{2}$, a mild oxidant, might damage the structure of the ANG II molecule, and thereby lead to a decrease in central ANG II-induced pressor responses. To exclude this possibility, a mix of ANG $(50 \mathrm{ng} / 1 \mu \mathrm{l})$ plus $\mathrm{H}_{2} \mathrm{O}_{2}(5 \mu \mathrm{mol} / 1 \mu \mathrm{l})$ was prepared and maintained at room temperature for at least $5 \mathrm{~min}$. Then, the mix was diluted to have $50 \mathrm{ng}$ of ANG II and $5 \mu \mathrm{mol}$ of $\mathrm{H}_{2} \mathrm{O}_{2}$ in a final volume of $0.1 \mathrm{ml}$, which was injected i.v. The cardiovascular responses produced by the mix of ANG II $+\mathrm{H}_{2} \mathrm{O}_{2}$ injected i.v. were compared with the responses produced by the same dose of ANG II injected i.v. alone $20 \mathrm{~min}$ before.

\section{RESULTS}

\section{Histological analysis}

Fig 1 shows the typical site of injections into the LV. As suggested by the histological analysis, i.c.v. injections of
$\mathrm{H}_{2} \mathrm{O}_{2}$ produced no damage of the neural tissue that might affect ANG II responses. Besides the histological analysis, another reason to exclude any influence of neural damage on the effects of $\mathrm{H}_{2} \mathrm{O}_{2}$ is the complete recovery of ANG II-induced pressor responses in rats that received a second injection of ANG II combined with saline i.c.v. (control) around $4 \mathrm{~h}$ after the first test in which they received ANG ॥ combined with $\mathrm{H}_{2} \mathrm{O}_{2}$ or ATZ i.c.v.

\section{Cardiovascular responses produced by ANG II i.c.v. combined with $\mathrm{H}_{2} \mathrm{O}_{2}$ or ATZ i.c.v.}

Fig. 2 shows representative recordings of pulsatile arterial pressure (PAP), MAP and HR in rats treated with vehicle, $\mathrm{H}_{2} \mathrm{O}_{2}(5 \mu \mathrm{mol} / 1 \mu \mathrm{l})$ or ATZ $(5 \mathrm{nmol} / 1 \mu \mathrm{l})$ i.c.v. combined with ANG II $(50 \mathrm{ng} / 1 \mu \mathrm{l})$ i.c.v.

The pressor response to ANG II $(50 \mathrm{ng} / 1 \mu \mathrm{l})$ i.c.v. was reduced by the pre-treatment with $\mathrm{H}_{2} \mathrm{O}_{2}(5 \mu \mathrm{mol} / 1 \mu \mathrm{l})$ i.c.v. $(7 \pm 3 \mathrm{~mm} \mathrm{Hg}$ vs. PBS: $19 \pm 4 \mathrm{~mm} \mathrm{Hg})[F(3,21)=14.3$; $P<0.05]$ (Fig 3). Injections of $\mathrm{H}_{2} \mathrm{O}_{2}(5 \mu \mathrm{mol} / 1 \mu \mathrm{l})$ i.c.v. alone produced no change on MAP. Injection of $\mathrm{H}_{2} \mathrm{O}_{2}$ and ANG II i.c.v. alone or combined produced no change on HR (Fig 3).

The pre-treatment with ATZ $(5 \mathrm{nmol} / 1 \mu \mathrm{l})$ i.c.v. also reduced the pressor response to ANG II $(50 \mathrm{ng} / 1 \mu \mathrm{l})$ i.c.v. $(5 \pm 3 \mathrm{~mm} \mathrm{Hg}$ vs. saline: $23 \pm 3 \mathrm{~mm} \mathrm{Hg})[F(3,36)=65.6$; $P<0.05$ ] (Fig 4). Injections of ATZ (5 nmol/1 $\mu$ l) i.c.v. alone produced no change on MAP or HR. Injection of ANG II i.c.v. alone produced no change on HR, however, ANG II i.c.v. reduced $H R$ after the pre-treatment with $A T Z$ $[F(3,36)=3.8 ; P<0.05]$ (Fig 4).

\section{Cardiovascular responses produced by ANG II i.v. or i.c.v. combined with ATZ i.v.}

Intravenous injections of ATZ ( $3.6 \mathrm{mmol} / \mathrm{kg}$ of body weight) reduced the pressor response to ANG II $(50 \mathrm{ng} / 1 \mu \mathrm{l})$ i.c.v. $(7 \pm 2 \mathrm{~mm} \mathrm{Hg}$, vs. saline: $21 \pm 1 \mathrm{~mm} \mathrm{Hg})[F(5,45)=65.5$; $P<0.05$ ] (Fig 5). However, ATZ (3.6 mmol/kg b.w.) i.v. did not affect the pressor response to ANG II $(50 \mathrm{ng} / 0.1 \mathrm{ml} / \mathrm{rat})$ i.v. ( $39 \pm 2 \mathrm{~mm} \mathrm{Hg}$, vs. saline: $41 \pm 3 \mathrm{~mm} \mathrm{Hg}$ ) (Fig 5).
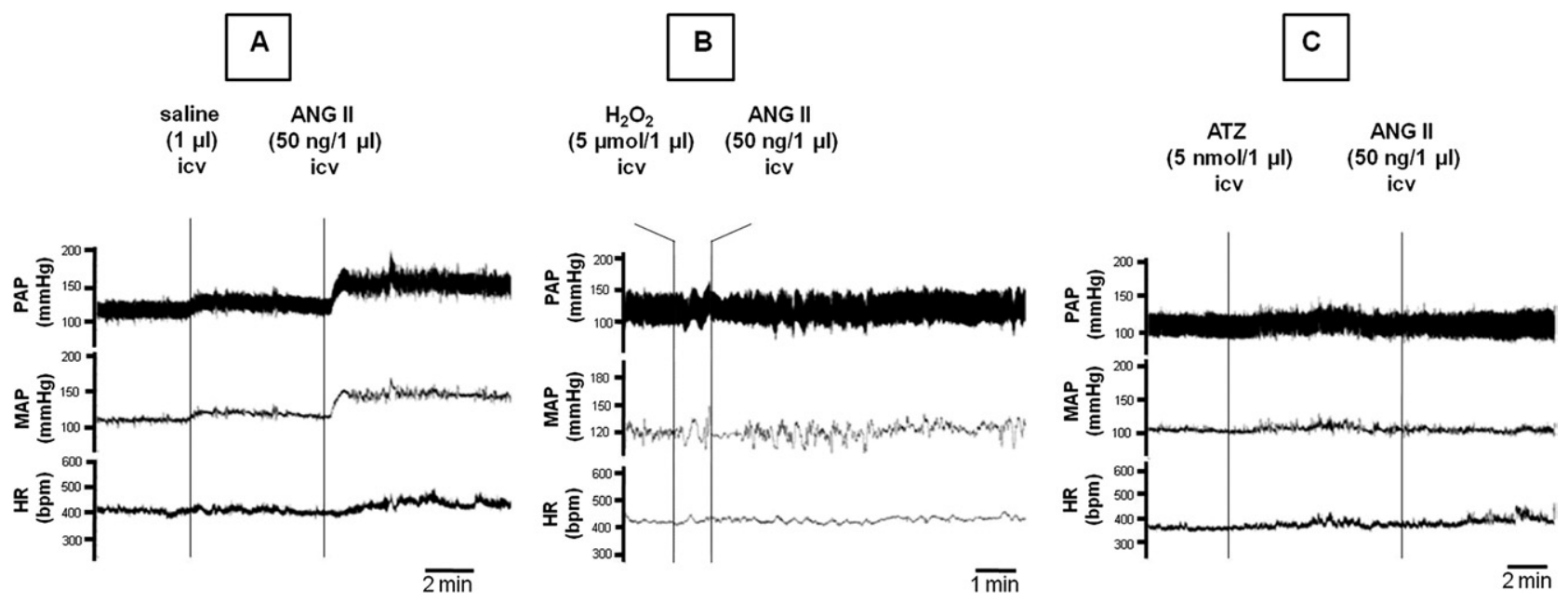

Fig. 2. Representative recordings showing changes in PAP, MAP and HR induced by i.c.v. ANG II (50 ng/1 $\mu$ l) after $(A)$ vehicle i.c.v., (B) $\mathrm{H}_{2} \mathrm{O}_{2}(5$ $\mu \mathrm{mol} / 1 \mu \mathrm{l})$ i.c.v. and (C) ATZ $(5 \mathrm{nmol} / 1 \mu \mathrm{l})$ i.c.v. 


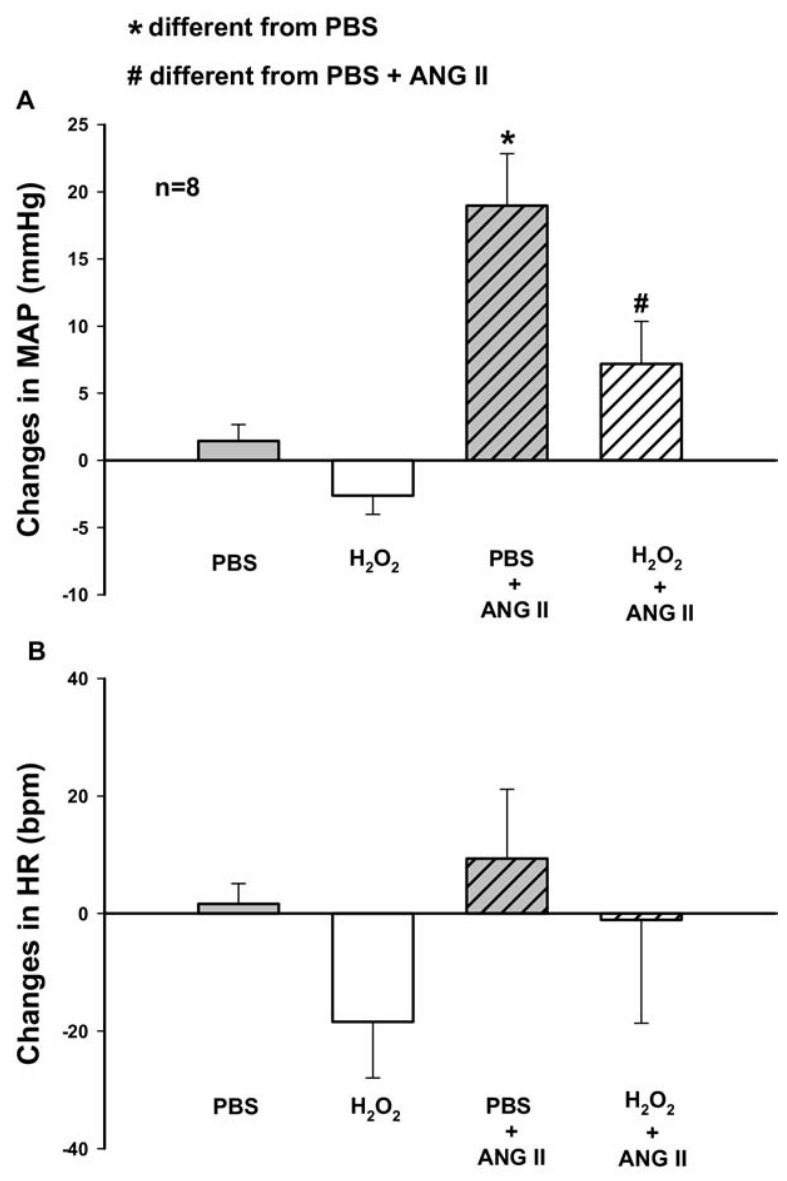

Fig. 3. Changes in (A) MAP and (B) $H R$ induced by i.c.v. injections of ANG II $(50 \mathrm{ng} / 1 \mu \mathrm{l})$ combined with i.c.v. injections of PBS or $\mathrm{H}_{2} \mathrm{O}_{2}(5$ $\mu \mathrm{mol} / 1 \mu \mathrm{l}$ ). The results are represented as means \pm SEM, $n=$ number of rats.

ANG II i.v. alone or combined with ATZ i.v. reduced HR (Fig 5). ANG II i.c.v. alone or combined with ATZ i.v. produced no change on HR (Fig 5).

Injection of ATZ (3.6 mmol/kg b.w.) i.v. alone did not modify MAP or HR (Fig 5).

\section{Cardiovascular responses produced by ANG II combined with $\mathrm{H}_{2} \mathrm{O}_{2}$ i.v.}

A potentially confounding factor is that $\mathrm{H}_{2} \mathrm{O}_{2}$, a mild oxidant, might damage the structure of the ANG II molecule, and thereby lead to a decrease in central ANG II-induced pressor responses. To exclude this possibility, the cardiovascular effects of i.v. injection of a mix of ANG II $+\mathrm{H}_{2} \mathrm{O}_{2}$ were tested.

Similar pressor and bradycardic responses were produced by i.v. injection of ANG II (50 ng/0.1 ml/rat) alone (48 $\pm 1 \mathrm{~mm} \mathrm{Hg}$ and $-62 \pm 14 \mathrm{bpm}$, respectively, $n=5$ rats) or mixed with $\mathrm{H}_{2} \mathrm{O}_{2}(5 \mu \mathrm{mol} / 0.1 \mathrm{ml} / \mathrm{rat})$ i.v. $(50 \pm 2 \mathrm{~mm} \mathrm{Hg}$ and $-62 \pm 10 \mathrm{bpm}$, respectively).

\section{DISCUSSION}

The present results show that i.c.v. injections of $\mathrm{H}_{2} \mathrm{O}_{2}$ or ATZ strongly decrease the pressor responses to i.c.v. ANG
II, suggesting that increased levels of $\mathrm{H}_{2} \mathrm{O}_{2}$ in the brain from exogenous or endogenous origin impair central pressor mechanisms activated by ANG II. I.v. injections of a high dose of ATZ also almost abolished the pressor responses to i.c.v. ANG II. However, i.v. ATZ or $\mathrm{H}_{2} \mathrm{O}_{2}$ did not change the response to i.v. ANG II, suggesting that these treatments do not affect pressor mechanisms activated by ANG II acting on blood vessels. Injections of ANG II, $\mathrm{H}_{2} \mathrm{O}_{2}$ or ATZ alone or combined produced no consistent effects on HR.

I.v. injection of a mix of ANG II and $\mathrm{H}_{2} \mathrm{O}_{2}$ that was prepared at the same concentration tested centrally and maintained at room temperature for at least $5 \mathrm{~min}$ produced pressor responses similar to those produced by injections of ANG II alone. These results again suggest that $\mathrm{H}_{2} \mathrm{O}_{2}$ does not affect the pressor mechanisms activated by ANG II acting peripherally and also that the effects of $\mathrm{H}_{2} \mathrm{O}_{2}$ reducing $A N G$ II responses are not related to any damage to the structure of ANG II molecule. Injections of $\mathrm{H}_{2} \mathrm{O}_{2}$ or ATZ i.c.v. at the doses tested also did not produce any neuronal destruction that might affect ANG II responses. The effect of i.c.v. $\mathrm{H}_{2} \mathrm{O}_{2}$ or ATZ reducing the
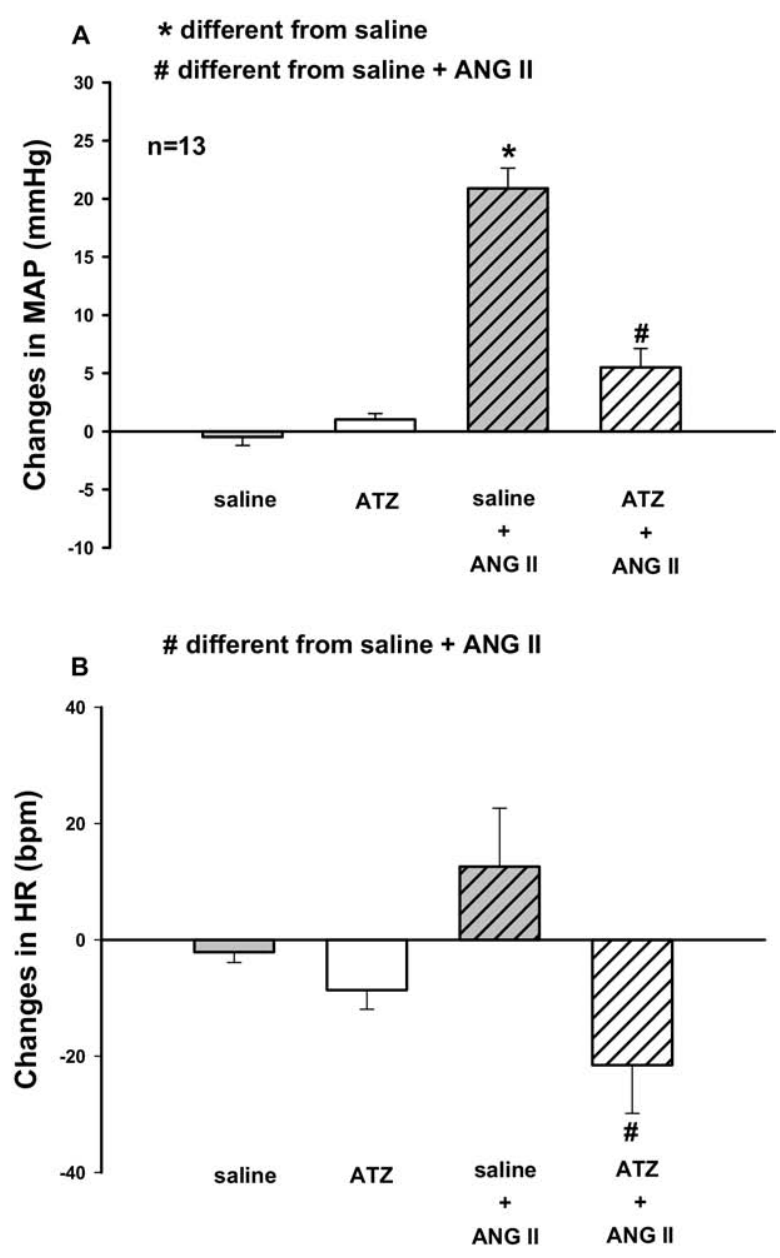

Fig. 4. Changes in (A) MAP and (B) HR induced by i.c.v. injections of ANG II $(50 \mathrm{ng} / 1 \mu \mathrm{l})$ combined with i.c.v. injections of saline or ATZ (5 $\mathrm{nmol} / 1 \mu \mathrm{l})$. The results are represented as means \pm SEM, $n=$ number of rats. 

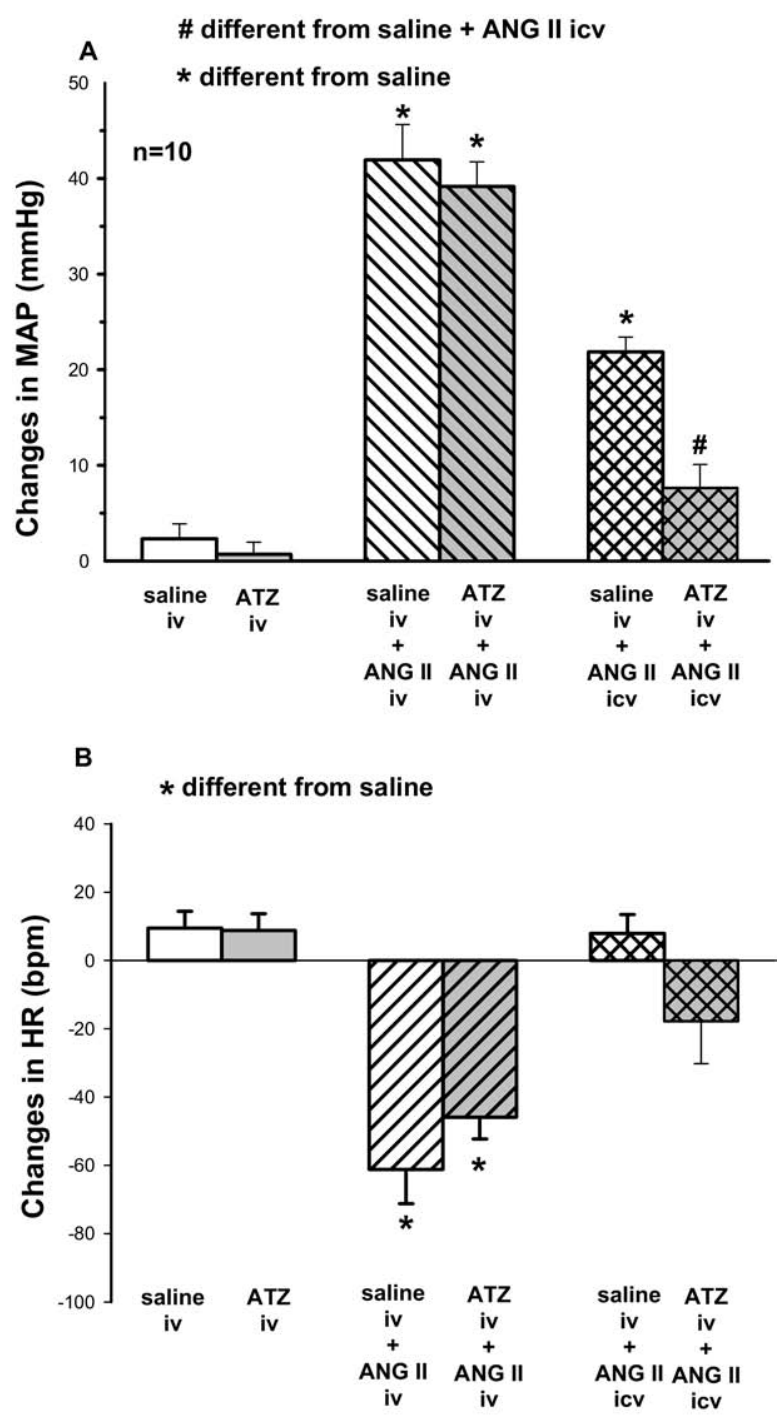

Fig. 5. Changes in (A) MAP and (B) HR induced by ANG II $(50 \mathrm{ng} / 1$ $\mu$ l) i.c.v. or ANG II $(50 \mathrm{ng} / 0.1 \mathrm{ml})$ i.v. combined with i.v. injections of saline or ATZ (3.6 mmol/kg body weight). The results are represented as means \pm SEM, $n=$ number of rats.

pressor responses to ANG II is transitory and a complete recovery of ANG II-induced pressor responses occurs when rats received a second injection of ANG II combined with saline i.c.v. (control) around $4 \mathrm{~h}$ after the first test in which they received ANG II combined with $\mathrm{H}_{2} \mathrm{O}_{2}$ or ATZ i.c.v. Therefore, any possible damage or destruction of ANG II receptors or neurons is also not the cause of the effects of $\mathrm{H}_{2} \mathrm{O}_{2}$.

The pressor response to central ANG II is strongly dependent on the activation of ANG II AT1 receptors, which are G-protein coupled and located in the neurons of the circumventricular organs that release facilitatory signals to increase vasopressin secretion and sympathetic activation (Johnson et al., 1978; Johnson, 1985; Hoffman et al., 1977; Mahon et al., 1995). The circumventricular organs directly activated by i.c.v. ANG II are the subfornical organ (SFO), organum vasculoso of lamina terminalis
(OVLT) and median preoptic nucleus (MnPO). From these sites, facilitatory signals may reach the paraventricular nucleus of the hypothalamus (PVN) and the rostroventrolateral medulla (RVLM) to increase sympathetic activity and PVN and supraoptic nucleus of the hypothalamus (SON) to increase vasopressin secretion (Hoffman et al., 1977; Johnson et al., 1978; Johnson, 1985; Mahon et al., 1995). Although $\mathrm{H}_{2} \mathrm{O}_{2}$ may act in any of these nuclei to reduce the pressor response to i.c.v. ANG II, the main areas involved in the effects of $\mathrm{H}_{2} \mathrm{O}_{2}$ are probably the circumventricular organs easily reached by $\mathrm{H}_{2} \mathrm{O}_{2}$ injected i.c.v. Therefore, without completely excluding other possibilities, $\mathrm{H}_{2} \mathrm{O}_{2}$ i.c.v. may act at the same sites or even at the same neurons directly activated by ANG II i.c.v.

Preliminary results from our laboratory have shown that $\mathrm{H}_{2} \mathrm{O}_{2}$ injected i.c.v. also reduces the pressor response induced by i.c.v. injections of the cholinergic agonist carbachol or the dipsogenic response to i.c.v. ANG II. Therefore, the effects of $\mathrm{H}_{2} \mathrm{O}_{2}$ injected centrally are not specific to ANG II-induced pressor responses. The pressor responses to central carbachol, similar to the pressor responses to central ANG II, depend on sympathetic activation and vasopressin release (Imai et al., 1989; Kubo, 1998), which suggests that $\mathrm{H}_{2} \mathrm{O}_{2}$ reduces pressor responses by reducing the activity of mechanisms that are common to ANG II and central cholinergic activation. Lesions of the anteroventral third ventricle (AV3V) region that includes the OVLT, MnPO and the periventricular preoptic nuclei almost abolish the pressor and dipsogenic responses to i.c.v. ANG II or carbachol, suggesting that important mechanisms for the pressor responses to icv ANG II or carbachol are present in this area (Brody et al., 1978; Johnson et al., 1978; Menani et al., 1990). Any substance injected into the lateral ventricle easily reaches the AV3V region and may affect responses dependent on the activity of this area. Therefore, $\mathrm{H}_{2} \mathrm{O}_{2}$ injected i.c.v. might reduce neuronal activity in the $A V 3 V$ region that is essential for the pressor response to i.c.v. ANG II. It is important to note that injections of $\mathrm{H}_{2} \mathrm{O}_{2}$ or ATZ into the lateral ventricle, similarly to AV3V lesions, reduce pressor responses to central ANG II, however, do not significantly modify baseline arterial pressure in normotensive rats, which again reinforces the suggestion that AV3V mechanisms might be those involved in the inhibition of ANG II-induced pressor responses by exogenous or endogenous $\mathrm{H}_{2} \mathrm{O}_{2}$ acting centrally, that is, removing AV3V pressor mechanisms by lesions or central $\mathrm{H}_{2} \mathrm{O}_{2}$ action affects pressor responses to i.c.v. ANG II without changing baseline arterial pressure. Although the present results showed no significant effect of $\mathrm{H}_{2} \mathrm{O}_{2}$ or ATZ injected i.v. or into the lateral ventricle on baseline MAP or $\mathrm{HR}$ in normotensive rats, previous studies showed that injections of $\mathrm{H}_{2} \mathrm{O}_{2}$ into the fourth ventricle, even at doses lower than the doses used in the present study, produced pressor and bradycardic responses, whereas injection of $\mathrm{H}_{2} \mathrm{O}_{2}$ or ATZ also in low doses into the nucleus of the solitary tract (NTS) induced hypotensive and bradycardic responses, suggesting that $\mathrm{H}_{2} \mathrm{O}_{2}$ may differently affect the mechanisms in- 
volved in cardiovascular control depending on the specific sites of action in the brain (Cardoso et al., 2006, 2009).

Acting centrally, $\mathrm{H}_{2} \mathrm{O}_{2}$ may affect neuronal excitability through different mechanisms which include changes in neurotransmitter release or ion channel activation. Studies have demonstrated that $\mathrm{H}_{2} \mathrm{O}_{2}$ can block glutamate uptake by glial cells, which may result in an increase of extracellular glutamate levels and enhanced neuronal excitability (Sorg et al., 1997; Volterra et al., 1994). Conversely, $\mathrm{H}_{2} \mathrm{O}_{2}$ may also reduce neuronal excitability as a consequence of the inhibition of glutamate or increase in GABA release or by the activation of $\mathrm{K}_{\text {ATP }}$ channels (Zoccarato et al., 1995, 1999; Sah et al., 2002; Takahashi et al., 2007; Bao et al., 2005; Avshalumov et al., 2005). The present results suggest that increased levels of $\mathrm{H}_{2} \mathrm{O}_{2}$ centrally reduce the facilitatory signals involved on central ANG II-induced pressor responses, however, they do not allow conclusion about which are the mechanisms activated by $\mathrm{H}_{2} \mathrm{O}_{2}$ centrally to reduce facilitatory signals produced by ANG II. As suggested above, $\mathrm{H}_{2} \mathrm{O}_{2}$ may act decreasing the neuronal activity in the AV3V region to reduce the pressor response to central ANG II. Further studies are necessary to investigate which are the central areas and mechanisms involved on $\mathrm{H}_{2} \mathrm{O}_{2}$-induced inhibition of ANG II responses.

The release of $\mathrm{O}_{2} \cdot-$ by the activation of central AT1 receptors is considered part of the signaling mechanisms activated by ANG II and an essential step for the activation of central mechanisms involved in the pressor and dipsogenic responses induced by ANG II acting centrally (Zimmerman et al., 2002, 2004a; Zimmerman and Davisson, 2004). Central SOD overexpression reduce $\mathrm{O}_{2}{ }^{-}-$levels centrally and the pressor response to central ANG II (Zimmerman et al., 2002, 2004a,b; Zimmerman and Davisson, 2004). Although changes in SOD activity do not necessarily affect $\mathrm{H}_{2} \mathrm{O}_{2}$ levels (Teixeira et al., 1998; Gardner et al., 2002; Chan et al., 2006; Kowald et al., 2006), the effects of $\mathrm{H}_{2} \mathrm{O}_{2}$ on the pressor responses to central ANG II raise questions about a possible involvement of $\mathrm{H}_{2} \mathrm{O}_{2}$ in the inhibition of ANG II-induced pressor and dipsogenic responses by SOD overexpression, which might be tested in future studies.

\section{CONCLUSION}

In summary, the present and previous results (Zimmerman et al., 2002, 2004a; Zimmerman and Davisson, 2004) suggest that $\mathrm{O}_{2}{ }^{--}$and $\mathrm{H}_{2} \mathrm{O}_{2}$ have opposite roles on central ANG II-induced pressor response. Considering that SOD may control the levels of these two ROS, this enzyme might have an important role in the modulation of the central effects of ANG II. However, with the present results it is not possible to exclude alternative sources and mechanisms for the inhibition of central ANG II-induced pressor responses by increased levels of $\mathrm{H}_{2} \mathrm{O}_{2}$ centrally.

Acknowledgments-The authors thank Silas Pereira Barbosa, Reginaldo da Conceição Queiróz and Silvia Fóglia for expert technical assistance, Silvana A. D. Malavolta for secretarial assistance, and Ana V. de Oliveira and Pedro Vieira for animal care. This research was supported by funding from Brazilian public research agencies (Fundação de Amparo à Pesquisa do Estado de São Paulo-FAPESP and Conselho Nacional de Desenvolvimento Científico e Tecnológico-CNPq).

\section{REFERENCES}

Adler V, Yin Z, Tew KD, Ronai Z (1999) Role of redox potential and reactive oxygen species in stress signaling. Oncogene 18:61046111.

Aizenman E, Lipton SA, Loring RH (1989) Selective modulation of NMDA responses by reduction and oxidation. Neuron 2:12571263.

Aragon CM, Rogan F, Amit Z (1991) Dose- and time-dependent effect of an acute 3-amino-1,2,4-triazole injection on rat brain catalase activity. Biochem Pharmacol 42:699-702.

Avshalumov MV, Chen BT, Kóos T, Tepper JM, Rice ME (2005) Endogenous hydrogen peroxide regulates the excitability of midbrain dopamine neurons via ATP-sensitive potassium channels. J Neurosci 25:4222-4231.

Bao L, Avshalumov MV, Patel JC, Lee CR, Miller EW, Chang CJ, Rice ME (2009) Mitochondria are the source of hydrogen peroxide for dynamic brain-cell signaling. J Neurosci 29:9002-9010.

Bao L, Avshalumov MV, Rice ME (2005) Partial mitochondrial inhibition causes striatal dopamine release suppression and medium spiny neuron depolarization via $\mathrm{H}_{2} \mathrm{O}_{2}$ elevation, not ATP depletion. J Neurosci 25:10029-10040.

Brody MJ, Fink GD, Buggy J, Haywood JR, Gordon FJ, Johnson AK (1978) The role of the anteroventral third ventricle (AV3V) region in experimental hypertension. Circ Res 43:1-13.

Campese VM, Sindhu RK, Ye S, Bai Y, Vaziri ND, Jabbari B (2007) Regional expression of $\mathrm{NO}$ synthase, $\mathrm{NAD}(\mathrm{P}) \mathrm{H}$ oxidase and superoxide dismutase in the rat brain. Brain Res 1134:27-32.

Cardoso LM, Colombari DSA, Menani JV, Chianca DA Jr., Colombari E (2006) Cardiovascular responses produced by central injection of hydrogen peroxide in conscious rats. Brain Res Bull 71:37-44.

Cardoso LM, Colombari DS, Menani JV, Toney GM, Chianca DA Jr., Colombari E (2009) Cardiovascular responses to hydrogen peroxide into the nucleus tractus solitarius. Am J Physiol 297:R462R469.

Chan SH, Tai MH, Li CY, Chan JYH (2006) Reduction in molecular synthesis or enzyme activity of superoxide dismutases and catalase contributes to oxidative stress and neurogenic hypertension in spontaneously hypertensive rats. Free Radic Biol Med 40:20282039.

Chen BT, Avshalumov MV, Rice ME (2001) $\mathrm{H}_{2} \mathrm{O}_{2}$ is a novel, endogenous modulator of synaptic dopamine release. J Neurophysiol 85:2468-2476.

Fitzsimons JT (1998) Angiotensin, thirst, and sodium appetite. Physiol Rev 78:583-686.

Gardner R, Salvador A, Moradas-Ferreira P (2002) Why does SOD overexpression sometimes enhance, sometimes decrease, hydrogen peroxide production? A minimalist explanation. Free Radic Biol Med 32:1351-1357.

Hoffman WE, Philips MI, Schmid PG, Falcon J, Weet JF (1977) Antidiuretic hormone release and the pressor response to central angiotensin II and cholinergic stimulation. Neuropharmacology 16:463-472.

Imai Y, Abe K, Sasaki N, Minami N, Munakata M, Yumita S, Nobunaga T, Sekino H, Yoshinaga K (1989) Role of vasopressin in cardiovascular responses to central cholinergic stimulation in rats. Hypertension 13:549-557.

Johnson AK, Hoffman WE, Buggy J (1978) Attenuated pressor responses to intracanially injected stimuli and altered antidiuretic activity following preoptic hypothalamic periventricular ablations. Brain Res 157:161-166.

Johnson AK (1985) The periventricular anteroventral third ventricle $(A \vee 3 V)$ : its relationship with the subfornical organ and neural sys- 
tem involved in maintaining body fluid homeostasis. Brain Res Bull 15:595-601.

Kowald A, Lehrach H, Klipp E (2006) Alternative pathways as mechanism for the negative effects associated with overexpression of superoxide dismutase. J Theor Biol 238:828-840.

Kubo T (1998) Cholinergic mechanism and blood pressure regulation in the central nervous system. Brain Res Bull 46:475-481.

Mahon JM, Allen M, Herbert J, Fitzsimons JT (1995) The association of thirst, sodium appetite and vasopressin release with c-fos expression in the forebrain of the rat after intracerebroventricular injection of angiotensin II, angiotensin-(1-7) or carbachol. Neuroscience 69:199-208.

Maker HS, Weiss C, Silides DJ, Cohen G (1981) Coupling of dopamine oxidation (monoamine oxidase activity) to glutathione oxidation via the generation of hydrogen peroxide in rat brain homogenates. J Neurochem 36:589-593.

Menani JV, Saad WA, Camargo LAA, Renzi A, De Luca LA Jr., Colombari E (1990) The anteroventral third ventricle (AV3V) region is essential for pressor, dipsogenic and natriuretic responses to central carbacol. Neurosci Lett 113:339-344.

Peterson JR, Burmeister MA, Tian X, Zhou Y, Guruju MR, Stupinski JA, Sharma RV, Davisson RL (2009) Genetic silencing of Nox2 and Nox4 reveals differential roles of these NADPH oxidase homologues in the vasopressor and dipsogenic effects of brain angiotensin II. Hypertension 54:1106-1114.

Rhee SG, Chang TS, Bae YS, Lee SR, Kang SW (2003) Cellular regulation by hydrogen peroxide. J Am Soc Nephrol 14(Suppl 3):S211-S215

Sah R, Galeffi F, Ahrens R, Jordan G, Schwartz-Bloom RD (2002) Modulation of the GABA(A)-gated chloride channel by reactive oxygen species. J Neurochem 80:383-391.

Sorg O, Horn TF, Yu N, Gruol DL, Bloom FE (1997) Inhibition of astrocyte glutamate uptake by reactive oxygen species: role of antioxidant enzymes. Mol Med 3:431-440.

Takahashi A, Mikami M, Yang J (2007) Hydrogen peroxide increases GABAergic mIPSC through presynaptic release of calcium from IP3 receptor-sensitive stores in spinal cord substantia gelatinosa neurons. Eur J Neurosci 25:705-716.
Teixeira HD, Schumacher RI, Meneghini R (1998) Lower intracellular hydrogen peroxide levels in cells overexpressing CuZn-superoxide dismutase. Proc Natl Acad Sci U S A 95:7872-7875.

Volterra A, Trotti D, Tromba C, Floridi S, Racagni G (1994) Glutamate uptake inhibition by oxygen free radicals in rat cortical astrocytes. J Neurosci 14:2924-2932.

Wehage E, Eisfeld J, Heiner I, Jüngling E, Zitt C, Lückhoff A (2002) Activation of the cation channel long transient receptor potential channel 2 (LTRPC2) by hydrogen peroxide. A splice variant reveals a mode of activation independent of ADP-ribose. J Biol Chem 277:23150-23156.

Zimmerman MC, Lazartigues E, Lang JA, Sinnayah P, Ahmad IM, Spitz DR, Davisson RL (2002) Superoxide mediates the actions of angiotensin II in the central nervous system. Circ Res 91: $1038-1045$.

Zimmerman MC, Davisson RL (2004) Redox signaling in central neural regulation of cardiovascular function. Prog Biophys Mol Biol $84: 125-149$

Zimmerman MC, Dunlay RP, Lazartigues E, Zhang Y, Sharma RV, Engelhardt JF, Davisson RL (2004a) Requirement for Rac1-dependent NADPH oxidase in the cardiovascular and dipsogenic actions of angiotensin II in the brain. Circ Res 95:532-539.

Zimmerman MC, Lazartigues E, Sharma RV, Davisson RL (2004b) Hypertension caused by angiotensin II infusion involves increased superoxide production in the central nervous system. Circ Res 95:210-216

Zimmerman MC, Sharma RV, Davisson RL (2005) Superoxide mediates angiotensin II-induced influx of extracellular calcium in neural cells. Hypertension 45:717-723.

Zoccarato F, Valente M, Alexandre A (1995) Hydrogen peroxide induces a long-lasting inhibition of the $\mathrm{Ca}(2+)$-dependent glutamate release in cerebrocortical synaptosomes without interfering with cytosolic Ca2+. J Neurochem 64:2552-2558.

Zoccarato F, Cavallini L, Valente M, Alexandre A (1999) Modulation of glutamate exocytosis by redox changes of superficial thiol groups in rat cerebrocortical synaptosomes. Neurosci Lett 274: 107-110. 